\title{
Successful use of montelukast in eosinophilic gastroenteritis: a case report and a literature review
}

\author{
Emran A. El-Alali ${ }^{*}$ (I), Ibrahim M. Abukhiran² and Tarik Z. Alhmoud ${ }^{3}$
}

\begin{abstract}
Background: Eosinophilic gastrointestinal disorders, also known as eosinophilic gastroenteritis, are rare inflammatory conditions characterized by eosinophilic infiltration of different parts of the gastrointestinal tract, along with peripheral eosinophilia in most cases. Other known causes for gut eosinophilic infiltration must be excluded to confirm the diagnosis of eosinophilic gastroenteritis. Symptoms of the disorder depend on the affected gastrointestinal tract segment and depth of involvement. Treatment includes systemic glucocorticoids and/or dietary therapy with an empiric elimination diet. Second line therapies include the leukotriene receptor antagonist montelukast, and other anti-allergy drugs such as mast cell stabilizers (including cromolyn and the $\mathrm{H} 1$-antihistamine ketotifen), suplatast tosilate which is a selective Th-2 cytokines (IL-4 and IL-5) inhibitor, and the monoclonal anti-lgE antibody omalizumab. We report a case of eosinophilic gastroenteritis who was successfully treated and achieved remission with montelukast as an initial monotherapy. Upon extensive literature review, this represents the second reported adult case of eosinophilic gastroenteritis who responds to montelukast alone as a first line therapy.
\end{abstract}

Case presentation: A 49-year-old female presented with recurrent abdominal pain, vomiting, diarrhea and unexplained eosinophilia. She was diagnosed with eosinophilic gastroenteritis and was successfully treated with montelukast monotherapy. After 7 days of therapy, the patient responded well and had complete resolution of her gastrointestinal symptoms and peripheral eosinophilia. Patient remained in remission on follow-up after 12 months. We reviewed the literature for leukotriene antagonist use in the treatment of eosinophilic gastroenteritis and included the cases treated with the leukotriene antagonist montelukast as an initial therapy or as a second line therapy for refractory disease.

Conclusion: Montelukast may be an effective treatment for eosinophilic gastroenteritis, either alone or in combination with systemic steroids or ketotifen. Our patient is the second reported adult case of eosinophilic gastroenteritis who responded to montelukast alone as a first line therapy. Further studies and clinical trials are required to confirm efficacy compared to standard therapy.

Keywords: Montelukast, Eosinophilic gastroenteritis, Leukotriene antagonist, Case report

*Correspondence: emranalali@yahoo.com; eelalali@aahs.org

1 Department of Internal Medicine, Anne Arundel Medical Center, 2001

Medical Pkwy, Annapolis, MD 21401, USA

Full list of author information is available at the end of the article

\section{Background}

Eosinophilic gastroenteritis (EGE) is a rare inflammatory condition that can affect patients of any age and is characterized by eosinophilic infiltration of different parts of the gastrointestinal tract. Stomach and/or duodenum are most commonly affected. Tissue and peripheral Eosinophilia are usually present. The inflammation occurs 
without any other underlying cause of eosinophilia. The estimated prevalence rate of EGE is 1.7-8.4 per 100,000 [1-3]. The rate of diagnosis has increased overtime [4].

Etiology is unclear, but an allergic component is highly suggested based on epidemiological and clinical features [5]. Although the role of food allergy in EGE has not been as clearly defined as with eosinophilic esophagitis, several reports have described an improvement in disease activity with an elimination diet [6].

Symptoms vary based on the location, extent and depth of involvement of the gastrointestinal tract. The most common symptoms of eosinophilic mucosal infiltration are abdominal pain, nausea, early satiety, vomiting, diarrhea and weight loss. Involvement of the muscular layer results in wall thickening and affects mobility, so patients may present with symptoms of intestinal obstruction. Patients with subserosal type of EGE usually present with ascites, either isolated or with symptoms of mucosal or muscular EGE.

The diagnosis of EGE is based on the presence of eosinophilic infiltration of the gastrointestinal (GI) tract on biopsy, lack of involvement of other organs and absence of other causes of intestinal eosinophilia by history, laboratory evaluation and other testing.

First line therapy is empiric elimination diet and/or systemic glucocorticoids depending on disease severity [7].

We report a case of a middle-age woman with EGE who responded to montelukast (MK), a leukotriene antagonist, as a first line treatment. She did not follow diet therapy instructions and refused systemic steroids. All symptoms of gastroenteritis and colitis including abdominal pain, vomiting and diarrhea, and peripheral eosinophilia resolved and she remained symptom free on a 12-month follow up.

The existing literature on the use of MK in EGE revealed one reported adult case who responded to MK as a first line monotherapy. Our literature search also revealed several cases of EGE who responded to MK when combined with other drugs or to $\mathrm{MK}$ as a second line therapy.

\section{Case presentation}

A 49-year-old Caucasian woman, with past medical history of diabetes mellitus type II, dyslipidemia and hypertension, presented to the emergency department with cramping-like abdominal pain, vomiting and diarrhea that started few weeks prior to presentation. Abdominal pain was generalized before becoming localized to the epigastrium, without radiation. No alleviating or aggravating factors were noted. She had frequent, watery to loose, non-bloody bowel movements.

Patient denied dysphagia or odynophagia, and had no fever, chills, skin rashes or joint pains. She denied any recent travel, sick contact or antibiotics use prior to onset of symptoms. Review of systems was unremarkable. Surgical history included cholecystectomy. Patient did not use tobacco, alcohol or illicit drugs. No family history of similar symptoms.

Patient was admitted to the hospital for further management. Prior to hospitalization, patient was evaluated and treated at two different healthcare facilities (including one hospital admission) for similar symptoms. There, she had a computed tomography (CT) scan of the abdomen and pelvis with contrast that showed fluid-filled bowels and thickened colonic wall, and she was released from the hospital on empirical antibiotics for presumed infectious enterocolitis, but symptoms recurred soon after hospital discharge.

On physical examination the patient appeared in moderate pain and distress. Vital signs showed an elevated blood pressure of $146 / 93 \mathrm{mmHg}$, heart rate of 88 beats per minute and a normal temperature of $36.5{ }^{\circ} \mathrm{C}$.

Abdominal exam showed generalized tenderness that was worse in the epigastrium with no rebound tenderness or abdominal distention. Bowel sounds were normal. There was no palpable organomegaly.

Eyelids showed xanthelasmas. Physical examination of heart, chest and extremities was normal.

Lab workup revealed peripheral eosinophilia; total white blood cells were 9,000 cells $/ \mu \mathrm{L}$ with $28 \%$ eosinophils (absolute eosinophil count of 2520 eosinophils $/ \mu \mathrm{L}$ ). Hemoglobin level was normal $(14.7 \mathrm{~g} / \mathrm{dL})$.

Lipase was $2831 \mathrm{IU} / \mathrm{L}$ (compared to $2415 \mathrm{IU} / \mathrm{L} 5$ days earlier on patient's recent hospitalization). Alkaline phosphatase was $391 \mathrm{IU} / \mathrm{L}$, with liver transaminases AST and ALT slightly higher than the normal range $(57 \mathrm{U} / \mathrm{L}$ and $54 \mathrm{U} / \mathrm{L}$, respectively) and a normal bilirubin level. Kidney function, lactic acid and electrolytes were within normal limits.

Erythrocyte sedimentation rate and C-reactive protein were within normal ranges $(10 \mathrm{~mm} / \mathrm{h}$ and $0.673 \mathrm{mg} / \mathrm{dL}$, respectively).

Evaluation for eosinophilia included a peripheral blood smear that showed an increased number of maturelooking eosinophils and no evidence of atypical cells or blasts. HIV test was negative. IgG-4 level was $40 \mathrm{mg} / \mathrm{dL}$ (normal $<86 \mathrm{mg} / \mathrm{dL}$ ). Chest X-ray showed no infiltrates or hilar adenopathy. Stool pathogen PCR panel was negative for Shigella, E. coli, Campylobacter, Clostridioides difficile toxin A/B, Salmonella, cryptosporidium and cyclospora and enteric viruses. Microscopic testing for stool ova and parasites was negative. All patient's medications were reviewed, and the possibility of drug-induced eosinophilia was excluded.

CT scan of the abdomen and pelvis showed diffuse fluid-filled loops of small and large bowel without 
bowel obstruction. Normal appearing pancreas with no evidence of inflammation or pseudocysts. No biliary dilatation and surgically absent gallbladder due to prior cholecystectomy. The liver and spleen were not enlarged and there was no lymph nodes enlargement.

A consultation for GI service was obtained, and because of the persistent unexplained symptoms and eosinophilia the patient underwent esophagogastroduodenoscopy (EGD), mucosal biopsies were obtained from the esophagus, stomach, duodenum and jejunum. Histological exam revealed eosinophilic-predominant mucosal inflammatory infiltrates in all biopsied specimens as shown in Fig. 1. Helicobacter Pylori was negative. No villous abnormality, cryptitis or crypt abscesses were identified. Diagnosis of eosinophilic gastroenteritis (EGE) and eosinophilic esophagitis was made.

Patient was initially managed with supportive therapy including nothing by mouth (NPO), intravenous (IV) fluid infusion and analgesia. No antibiotics were given during the last hospital admission. Patient refused to start therapy with steroids due to concerns about adverse effects. She was started on montelukast $10 \mathrm{mg}$ once a day by mouth and discharged home to follow as an outpatient. Abdominal pain, vomiting and diarrhea resolved over 1 week of treatment.

Clinic follow-up was made 5 months and 12 month post hospitalization. The patient reported no further symptoms and reported adherence to montelukast therapy without any adverse effects. Complete blood count $(\mathrm{CBC})$ was repeated with findings of normal eosinophils [absolute eosinophil count of 170 eosinophils/ $\mu \mathrm{L}$ ].

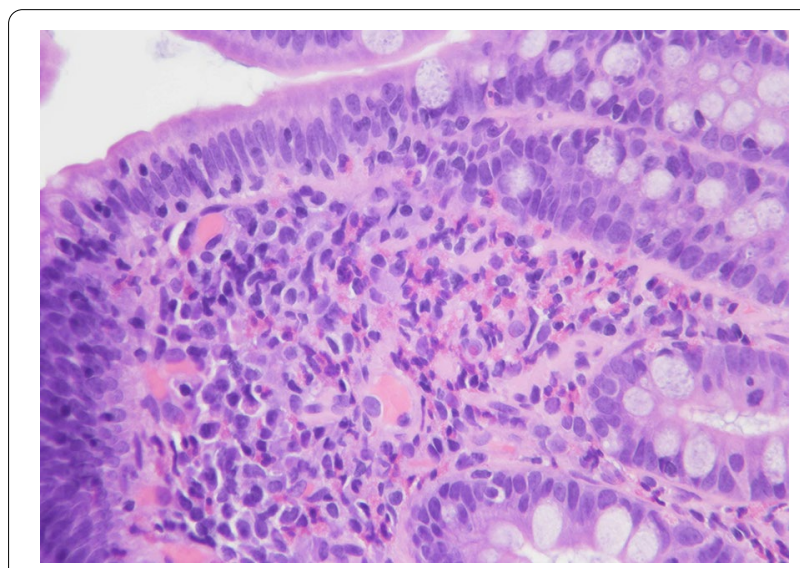

Fig. 1 Duodenum biopsy showing markedly increased eosinophils (> 20/hpf) in lamina propria with focal epithelial involvement. (Hematoxylin and Eosin 40x)

\section{Discussion}

This is a case of a 49-year-old woman who suffered from multiple gastrointestinal symptoms including nausea, vomiting, abdominal pain and diarrhea, which are commonly encountered in the healthcare setting. She presented to the emergency department few times and was hospitalized without identifying the underlying diagnosis, and had no relief of her symptoms. We were involved in the care of this patient on the second hospital admission, and based on the constellation of symptoms, laboratory results and $\mathrm{CT}$ scan findings we came to an initial differential diagnosis of infectious gastroenteritis or parasitic infection. Acute pancreatitis with ileus was a concern due to markedly elevated lipase, however, the absence of typical pancreatitis-related epigastric pain and the normal appearance of pancreas on two CT scans ruled out pancreatitis as a cause for her symptoms. Stool microbiology studies excluded viral, bacterial or parasitic infections. Patient did not respond to standard therapies including antibiotics (at the initial hospital admission), bowel rest with NPO, analgesia and IV fluids administration.

Given that the patient had persistent unexplained peripheral eosinophilia, bowel wall thickening on CT scan and negative workup for common disorders, along with the non-resolving nature of symptoms despite standard treatment, a diagnosis of eosinophilic gastrointestinal disorder was presumed. Upper endoscopy with biopsies confirmed the diagnosis of EGE (mucosal type), based on histopathologic findings of abundant eosinophils in the gastric, duodenal and jejunal mucosa. Montelukast (MK) was then started based on patient's preferences and concerns about corticosteroids adverse effects. She responded well and became asymptomatic over 1 week of therapy, and peripheral eosinophil count has normalized. Patient remained in remission during follow-up 12 months later.

EGE is a rare disease, therefore evidence for treatment is based on limited case reports and clinicians' experience [8]. MK is a safe medicine and has a low side effect profile compared to systemic steroids [9]. MK is a selective and competitive leukotriene receptor inhibitor. Cysteinyl leukotrienes have potent chemoattractant properties for eosinophils. Together with interleukin 3 and 5, cysteinyl leukotrienes play a major role in the recruitment of eosinophils into the affected tissue leading to tissue damage [10].

\section{Literature review}

We reviewed the literature on montelukast (MK) use in EGE cases and summarized the reported cases in Tables 1, 2 and 3. MEDLINE, Embase and Google scholar 
Table 1 Montelukast (MK) as a first line monotherapy in eosinophilic gastroenteritis (EGE)

\begin{tabular}{|c|c|c|c|c|c|c|}
\hline Authors & Study design & $\begin{array}{l}\text { Number of } \\
\text { patients, } \\
\text { gender } \\
(\mathrm{M} \%) \text {, } \\
\text { mean } \\
\text { age } \pm \text { SD } \\
\text { (years) }\end{array}$ & Affected segments & Dose, duration & $\begin{array}{l}\text { Outcomes: } \\
\text { EGE symptoms, } \\
\text { tissue eosinophilia } \\
\text { (if reported) }\end{array}$ & Follow-up duration \\
\hline \multicolumn{7}{|l|}{ Adult cases } \\
\hline Wong et al. [11] & $\begin{array}{l}\text { Retrospective case } \\
\text { series }^{a}\end{array}$ & One M, & - & $\begin{array}{l}10 \text { mg daily, } \\
1 \text { month }\end{array}$ & $\begin{array}{l}\text { Symptoms improved, } \\
-\end{array}$ & 10 months \\
\hline \multicolumn{7}{|l|}{ Pediatric cases } \\
\hline Tien et al. [12] & $\begin{array}{l}\text { Retrospective case } \\
\text { series }^{\text {a }}\end{array}$ & $\begin{array}{l}4 \\
M 75 \% \\
8 \pm 4.3^{b}\end{array}$ & $\begin{array}{l}\text { Stomach and duode- } \\
\text { num }\end{array}$ & 5 mg daily, & $\begin{array}{l}\text { Symptoms resolved in } \\
4 / 4 \text { cases, } \\
\text { Eosinophilia improved } \\
3 / 3 \text { cases }\end{array}$ & 12 months \\
\hline Selva Kumar et al. [13] & Case report & $\begin{array}{l}\text { One } \mathrm{F}, \\
12\end{array}$ & $\begin{array}{l}\text { Stomach and duode- } \\
\text { num }\end{array}$ & $\begin{array}{l}10 \text { mg daily, } \\
1 \text { month }\end{array}$ & $\begin{array}{l}\text { Symptoms and eosin- } \\
\text { ophilia resolved }\end{array}$ & - \\
\hline $\begin{array}{l}\text { Neustrom and Friesen } \\
\text { [14]9 }\end{array}$ & Case report & $\begin{array}{l}\text { One F, } \\
13\end{array}$ & $\begin{array}{l}\text { Esophagus, stomach } \\
\text { and duodenum }\end{array}$ & 10 mg daily, & $\begin{array}{l}\text { Symptoms resolved, } \\
\text { Eosinophilia } \\
\text { decreased }\end{array}$ & 4 months \\
\hline
\end{tabular}

databases were searched for case reports, case series and clinical trials using the following terms: "eosinophilic gastroenteritis", "eosinophilic gastritis", eosinophilic duodenitis", "eosinophilic colitis" AND "montelukast" OR "leukotriene antagonist". Studies that confirmed the diagnosis of EGE using the following criteria were included: Symptoms of EGE including abdominal pain, nausea, vomiting, diarrhea, weight loss, failure to thrive or iron deficiency anemia; eosinophilic infiltrate $\geq 20 / \mathrm{hpf}$; and absence of other causes of eosinophilia or eosinophilic infiltrate. Studies that used a lower cutoff for eosinophilic infiltrate (i.e., $<20 / \mathrm{hpf}$ ) or used the diagnosis of "functional dyspepsia with eosinophilia or duodenal eosinophilia" were excluded. Cases of eosinophilic esophagitis were also excluded.

Our patient is the second adult case of EGE in the literature who successfully responds to initial MK monotherapy, and the first reported adult Caucasian patient. Wong et al. reported one adult case and six pediatric cases in an Asian population. Our patient remained on MK for 1 year, during which she maintained remission, whereas the adult patient reported by Wong et al. used MK for 1 month and remained in remission after 12 months. In one systematic review, EGE was found to occur in Asians more than Caucasians, while eosinophilic esophagitis had an opposite trend [28]. Table 1 describes the reported use of MK as a first line monotherapy in a total of seven EGE cases.

Table 2 shows the use of MK in EGE as an initial combination therapy with systemic glucocorticoids in a total of 13 patients (including 5 adults); 46\% responded well and had symptoms resolution (100\% of the adult cases) while on glucocorticoid and MK combination therapy. In a large case series of 64 patients, MK was combined with the mast cell stabilizer and $\mathrm{H} 1$ antagonist ketotifen; $89 \%$ responded well to this combination with resolution of symptoms [16].

Table 3 describes the successful use of MK as a steroid-sparing agent in a total of eight patients ( $63 \%$ adults) [20-26], or as a second line therapy after failing corticosteroids in one child with EGE [27].

The merits of our approach for induction of remission using $M K$ is that MK is a safe medication with a lower side effects profile compared to systemic corticosteroids. The limitations to our approach is the absence of large prospective studies to prove and support its effectiveness, duration and long term use for this purpose in EGE.

Based on data from our patient and from similar case reports, we suggest the use of MK for at least one month to induce remission in EGE 
Table 2 Use of montelukast (MK) as part of an initial combination therapy in eosinophilic gastroenteritis (EGE)

\begin{tabular}{|c|c|c|c|c|c|}
\hline Authors & Study design & $\begin{array}{l}\text { Number of patients, } \\
\text { gender (M\%), } \\
\text { mean age } \pm S D \\
\text { (years) }\end{array}$ & Affected segments & $\begin{array}{l}\text { Medications used, } \\
\text { duration (if known) }\end{array}$ & $\begin{array}{l}\text { Outcomes: EGE } \\
\text { symptoms, tissue } \\
\text { eosinophilia and } \\
\text { follow-up duration (if } \\
\text { reported) }\end{array}$ \\
\hline Priyadarshni et al. [16] & Case report & $\begin{array}{l}\text { One M, } \\
28\end{array}$ & $\begin{array}{l}\text { Stomach and small } \\
\text { bowel }\end{array}$ & $\begin{array}{l}\text { Prednisone and mon- } \\
\text { telukast (dose/dura- } \\
\text { tion: not reported) }\end{array}$ & Symptoms resolved \\
\hline Hui and Hui [15] & Prospective & $\begin{array}{l}64 \\
M 63 \% \\
40.5 \pm 23.5^{b}\end{array}$ & $\begin{array}{l}\text { Terminal ileum and/or } \\
\text { colon }\end{array}$ & $\begin{array}{l}\text { Ketotifen } 1 \text { mg daily up } \\
\text { to } 2 \text { mg twice daily } \\
\text { and montelukast } \\
10 \text { mg daily, } \\
16 \text { weeks }\end{array}$ & $\begin{array}{l}\text { Symptoms resolved in } \\
57 \text { of } 64(89.1 \%)\end{array}$ \\
\hline Chen et al. [17] & Care report & $\begin{array}{l}\text { One } M, \\
54\end{array}$ & $\begin{array}{l}\text { Stomach and duode- } \\
\text { num }\end{array}$ & $\begin{array}{l}\text { Methylprednisolone } \\
30 \text { mg daily and } \\
\text { montelukast } 4 \text { mg daily, } \\
1 \text { month }\end{array}$ & $\begin{array}{l}\text { Symptoms resolved, } \\
\text { Eosinophilia improved }\end{array}$ \\
\hline Wong et al. [11] & $\begin{array}{l}\text { Retrospective case } \\
\text { series }^{\mathrm{a}}\end{array}$ & $\begin{array}{l}\text { One } \mathrm{M}, \\
-\end{array}$ & - & $\begin{array}{l}\text { Prednisolone } \\
30-40 \mathrm{mg} / \text { day } \\
\text { tapered over } \\
\text { 1-3 months and } \\
\text { montelukast (MK } \\
\text { dose/duration: } \\
\text { unknown) }\end{array}$ & $\begin{array}{l}\text { Symptoms and eosino- } \\
\text { philia resolved, } \\
36 \text { months }\end{array}$ \\
\hline Baek et al. [18] & Case report & $\begin{array}{l}\text { One } F \\
68\end{array}$ & Duodenum & $\begin{array}{l}\text { Prednisolone } 30 \mathrm{mg} \\
\text { daily, } \\
1 \text { month } \\
\text { Montelukast } 10 \mathrm{mg} \\
\text { daily, } \\
5 \text { months }\end{array}$ & $\begin{array}{l}\text { Symptoms and eosino- } \\
\text { philia resolved }\end{array}$ \\
\hline Milić et al. [19] & Case report & $\begin{array}{l}\text { One } F \\
30\end{array}$ & $\begin{array}{l}\text { Esophagus, stomach, } \\
\text { small and large } \\
\text { intestine }\end{array}$ & $\begin{array}{l}\text { Prednisone } 40 \mathrm{mg} \text { daily } \\
\text { Montelukast } 10 \mathrm{mg} \\
\text { daily, } \\
2 \text { weeks }\end{array}$ & Symptoms resolved \\
\hline \multicolumn{6}{|l|}{ Pediatric cases } \\
\hline Tien et al. [12] & $\begin{array}{l}\text { Retrospective case } \\
\text { series }^{\mathrm{a}}\end{array}$ & $\begin{array}{l}8 \\
M 63 \% \\
7.9 \pm 6.5^{b}\end{array}$ & $\begin{array}{l}\text { Stomach and duode- } \\
\text { num }\end{array}$ & $\begin{array}{l}\text { Corticosteroids (CS) } \\
1-2 \mathrm{mg} / \mathrm{kg} / \mathrm{day} \\
\mathrm{CS} \text { and MK in } 6 / 8 \\
\mathrm{CS} \text { and MK and } \\
\text { Ketotifen in 2/8, } \\
\text { Duration: unknown }\end{array}$ & $\begin{array}{l}\text { 1/8 (12.5\%) in remission } \\
\text { (on CS and MK) }\end{array}$ \\
\hline
\end{tabular}

$M$ male, $F$ female, $m g$ milligrams, $M K$ montelukast, $S D$ standard deviation

${ }^{\text {a Asian population }}$

${ }^{\mathrm{b}}$ Mean age $\pm S D$ for all study population.

\section{Conclusion}

Montelukast (MK) might be an effective treatment for EGE when used as an initial therapy alone, in combination with systemic steroids or ketotifen, or as a steroid-sparing agent. Our patient is the second reported adult case of EGE with successful remission following treatment with MK alone. The majority of reports in the literature concerning MK use in EGE have shown positive and promising outcomes. Larger prospective series and clinical trials are needed to further delineate the use of MK treatment in EGE, to include the exact dosage, duration and long-term outcomes. 
Table 3 Reported use of Montelukast (MK) as a subsequent or adjunctive therapy in eosinophilic gastroenteritis (EGE)

\begin{tabular}{|c|c|c|c|c|c|c|}
\hline Author(s) & Study design & $\begin{array}{l}\text { Number of } \\
\text { patients, } \\
\text { gender (M\%), } \\
\text { mean age } \pm \text { SD } \\
\text { (years) }\end{array}$ & Affected segments & $\begin{array}{l}\text { Medication(s) prior } \\
\text { to starting MK, } \\
\text { MK dose and } \\
\text { duration (if known) }\end{array}$ & Outcomes & Follow up duration \\
\hline \multicolumn{7}{|l|}{ Adult cases } \\
\hline Schwartz et al. [24] & Case report & $\begin{array}{l}\text { One } M \\
27\end{array}$ & Small intestine & $\begin{array}{l}\text { Prednisone } 20 \mathrm{mg} \\
\text { daily } \\
\text { (induction for } \\
4 \text { weeks), } \\
\text { Montelukast } 10 \mathrm{mg} \\
\text { daily, } \\
20 \text { months }\end{array}$ & Symptoms resolved & 20 months \\
\hline Muller et al. [22] & Prospective & $\begin{array}{l}\text { Two, } \\
- \\
39.5 \pm 19.5^{b}\end{array}$ & $\begin{array}{l}\text { Stomach and small } \\
\text { intestine }\end{array}$ & $\begin{array}{l}\text { Prednisolone } 40 \text { m } \\
\text { daily, } \\
\text { Montelukast (dose/ } \\
\text { duration: not } \\
\text { reported) }\end{array}$ & Symptoms resolved & $14 \pm 5.6$ months \\
\hline De Maeyer et al. [21] & Case report & $\begin{array}{l}\text { One M, } \\
38\end{array}$ & Duodenum & $\begin{array}{l}\text { Methylpredniso- } \\
\text { lone } 16 \text { mg daily } \\
\text { (tapered to } 4 \mathrm{mg} \text { ) } \\
\text { Montelukast } 10 \mathrm{mg} \\
\text { daily }\end{array}$ & $\begin{array}{l}\text { Symptoms } \\
\text { improved }\end{array}$ & Unknown \\
\hline Urek et al. [25] & Case report & $\begin{array}{l}\text { One } M \\
18\end{array}$ & Serosal disease & $\begin{array}{l}\text { Prednisolone } 20 \text { mg } \\
\text { daily } \\
\text { Montelukast } 10 \mathrm{mg} \\
\text { daily }\end{array}$ & $\begin{array}{l}\text { Remission after } \\
4 \text { weeks of mon- } \\
\text { telukast }\end{array}$ & Unknown \\
\hline \multicolumn{7}{|l|}{ Pediatric cases } \\
\hline Lu and Ballas [23] & Retrospective & $\begin{array}{l}\text { Two, } \\
\text { M 50\%, } \\
17 \text { and } 39\end{array}$ & - & $\begin{array}{l}\text { Prednisone } \\
26-40 \mathrm{mg} \text { QOD } \\
\text { Prednisone } 30 \mathrm{mg} \\
\text { daily }\end{array}$ & $\begin{array}{l}\text { MK decreased pred- } \\
\text { nisone require- } \\
\text { ment to } 10 \mathrm{mg} \\
\text { QOD in pediatric } \\
\text { case }\end{array}$ & Unknown \\
\hline Quack et al. [20] & Case report & $\begin{array}{l}\text { One F, } \\
17\end{array}$ & $\begin{array}{l}\text { Esophagus, stomach, } \\
\text { ileum and colon }\end{array}$ & $\begin{array}{l}\text { Prednisone } 40 \text { mg } \\
\text { daily (tapered to } \\
10 \text { mg: relapsed) } \\
\text { Montelukast } 10 \mathrm{mg} \\
\text { daily }\end{array}$ & Symptoms resolved & 24 months \\
\hline Menon et al. [26] & Case report & $\begin{array}{l}\text { One F, } \\
11\end{array}$ & $\begin{array}{l}\text { Stomach and small } \\
\text { bowel }\end{array}$ & $\begin{array}{l}\text { Prednisolone (P): } \\
\text { Relapsed after } \\
\text { discontinuation } \\
\text { Montelukast: Added } \\
\text { to } 5 \text { mg P }\end{array}$ & Symptoms resolved & Unknown \\
\hline Vithayasai et al. [27] & Retrospective $^{a}$ & $\begin{array}{l}\text { One, } \\
- \\
6.75 \pm 6.25^{\mathrm{b}}\end{array}$ & - & $\begin{array}{l}\text { Prednisolone (failed) } \\
\text { Montelukast and } \\
\text { ketotifen were } \\
\text { started }\end{array}$ & No relapses & 3 months to 5 years \\
\hline
\end{tabular}

QOD every other day, $F$ female, $M$ male, $m g$ milligrams, $M K$ montelukast, SD standard deviation

${ }^{\text {a }}$ Asian population

${ }^{\mathrm{b}}$ Mean age $\pm S D$ for all study population

\section{Abbreviations}

EGE: Eosinophilic gastroenteritis; MK: Montelukast; Gl: Gastrointestinal; CT: Computed tomography; NPO: Nil per os (nothing by mouth); IV: Intravenous: EGD: Esophagogastroduodenoscopy.

\section{Acknowledgements}

Mrs. Miller has contributed to the literature search and review. Dr. Sharma has participated in medical management of the reported case in this manuscript.

\section{Authors' contributions}

EE contributed to the conception of the manuscript; acquisition and analysis of data; drafting, editing and critically revising the manuscript and performed the literature search; final approval of the work; and agreed to be accountable for all aspects of the work. IA contributed to the design of manuscript; critically revised the pathology report and edited the manuscript; final approval of the work; and agreed to be accountable for the work. TA contributed to the design of manuscript; critically revised and edited the manuscript and assisted in literature review; final approval of the work; and agreed to be accountable for the work. All authors read and approved the final manuscript. 


\section{Funding}

No grant support, funding or writing assistance were provided to assist in this manuscript preparation.

\section{Availability of data and materials}

The datasets used and/or analysed during the current study are available from the corresponding author on reasonable request.

\section{Declarations}

\section{Ethics approval and consent to participate}

The need for ethics approval and consent is waived by Anne Arundel Medical Center (AAMC) Clinical Research Committee. AAMC Clinical Research Committee director: Erika Siegrist MS, RN, ACRP-CP, phone: + 1 (443) 4811320, e-mail: esiegrist@aahs.org.

\section{Consent for publication}

A written informed consent was obtained from the patient for publication of this case report and any accompanying images.

\section{Competing interests}

The authors declare that they have no competing interests.

\section{Author details}

${ }^{1}$ Department of Internal Medicine, Anne Arundel Medical Center, 2001 Medical Pkwy, Annapolis, MD 21401, USA. ${ }^{2}$ Anatomic and Clinical Pathology, University of lowa Hospitals and Clinics, 200 Hawkins Dr, lowa City, lowa, USA ${ }^{3}$ Promedica Digestive Health Care, 5700 Monroe St, Suite 103, Sylvania, OH USA

Received: 15 February 2021 Accepted: 21 June 2021

Published online: 08 July 2021

\section{References}

1. Alhmoud T, Hanson JA, Parasher G. Eosinophilic gastroenteritis: an underdiagnosed condition. Dig Dis Sci. 2016;61. https://doi.org/10.1007/ s10620-016-4203-5.

2. Mansoor E, Saleh MA, Cooper GS. Prevalence of eosinophilic gastroenteritis and colitis in a population-based study, from 2012 to 2017. Clin Gastroenterol Hepatol. 2017;15. https://doi.org/10.1016/j.cgh.2017.05. 050.

3. Jensen ET, Martin CF, Kappelman MD. Prevalence of eosinophilic gastritis, gastroenteritis, and colitis: estimates from a national administrative database. J Pediatr Gastroenterol Nutr. 2016;62. https://doi.org/10.1097/MPG. 0000000000000865

4. Pesek RD, Reed CC, Muir AB, Fulkerson PC, Menard-Katcher C, Falk GW, et al. Increasing rates of diagnosis, substantial co-occurrence, and variable treatment patterns of eosinophilic gastritis, gastroenteritis and colitis based on 10 year data across a multi-center consortium. Am J Gastroenterol. 2019;114:984.

5. Talley NJ, Shorter RG, Phillips SF, Zinsmeister AR. Eosinophilic gastroenteritis: a clinicopathological study of patients with disease of the mucosa, muscle layer, and subserosal tissues. Gut. 1990;31. https://doi.org/10. 1136/gut.31.1.54.

6. Ko HM, Morotti RA, Yershov O, Chehade M. Eosinophilic gastritis in children: clinicopathological correlation, disease course, and response to therapy. Am J Gastroenterol. 2014;109. https://doi.org/10.1038/ajg.2014. 166.

7. Antoine Abou Rached WEH. Eosinophilic gastroenteritis: approach to diagnosis and management. World J Gastrointest Pharmacol Ther. 2016;7:513.

8. Shih HM, Bair MJ, Chen HL, Lin IT. Eosinophilic Gastroenteritis: brief review. Acta Gastroenterol Belg. 2016;79. https://pubmed.ncbi.nlm.nih. gov/27382945/.
9. Oray M, Abu Samra K, Ebrahimiadib N, Meese H, Foster CS. Long-term side effects of glucocorticoids. Expert Opin Drug Saf. 2016;15. https://doi. org/10.1517/14740338.2016.1140743.

10. Straumann A, Simon HU. The physiological and pathophysiological roles of eosinophils in the gastrointestinal tract. Allergy. 2004;59. https://doi. org/10.1046/j.1398-9995.2003.00382.x.

11. Wong GW, Lim KH, Wan WK, Low SC, Kong SC. Eosinophilic gastroenteritis: clinical profiles and treatment outcomes, a retrospective study of 18 adult patients in a Singapore Tertiary Hospital. Med J Malaysia. 2015:70. Available: https://pubmed.ncbi.nlm.nih.gov/26358020/.

12. Tien FM, Wu JF, Jeng YM, Hsu HY, Ni YH, Chang MH, et al. Clinical features and treatment responses of children with eosinophilic gastroenteritis. Pediatr Neonatol. 2011;52. https://doi.org/10.1016/j.pedneo.2011.06.006.

13. C SK, Das RR, Balakrishnan CD, Balagurunathan K, Chaudhuri K. Malabsorption syndrome and leukotriene inhibitor. J Trop Pediatr. 2011;57. https://doi.org/10.1093/tropej/fmq052.

14. Neustrom MR, Friesen C. Treatment of eosinophilic gastroenteritis with montelukast. J Allergy Clin Immunol. 1999;104. https://doi.org/10.1016/ s0091-6749(99)70404-5.

15. Hui CK, Hui NK. A prospective study on the prevalence, extent of disease and outcome of eosinophilic gastroenteritis in patients presenting with lower abdominal symptoms. Gut Liver. 2018;12. https://doi.org/10.5009/ gnl17056.

16. Priyadarshni S, Surapaneni BK, Dave K, Kaplan S, Patel N. Upper gastrointestinal bleed in a young male- a rare presentation of eosinophilic gastroenteritis. Cureus. 2020;12. https://doi.org/10.7759/cureus.7059.

17. Chen B, Yang Z, Lu H, Wei C, Wang F, Liu C. Eosinophilic gastroenteritis presenting as upper gastrointestinal hematoma and ulcers after endoscopic biopsy: A case report and literature review. Medicine . 2017:96. https://doi.org/10.1097/MD.0000000000008075.

18. Baek MS, Mok YM, Han WC, Kim YS. A patient with eosinophilic gastroenteritis presenting with acute pancreatitis and ascites. Gut Liver. 2014;8. https://doi.org/10.5009/gnl.2014.8.2.224.

19. Milić S, Poropat G, Malić D, Stimac D. A case of postpartum eosinophilic gastroenteritis and review of the literature. Dig Dis. 2012:30. https://doi. org/10.1159/000336711.

20. Quack I, Sellin L, Buchner NJ, Theegarten D, Rump LC, Henning BF. Eosinophilic gastroenteritis in a young girl - long term remission under Montelukast. BMC Gastroenterol. 2005;5:24.

21. De Maeyer N, Kochuyt AM, Van Moerkercke W, Hiele M. Montelukast as a treatment modality for eosinophilic gastroenteritis. Acta Gastroenterol Belg. 2011;74. Available: https:/pubmed.ncbi.nlm.nih.gov/22319970/.

22. Muller M. Clinicopathologic Findings in Eosinophilic Gastroenteritis: a German Case Series. J Genet Syndr Gene Ther. 2014;05. https://doi.org/10 4172/2157-7412.1000230.

23. Lu E, Ballas ZK. Immuno-modulation in the treatment of eosinophilic gastroenteritis. J Allergy Clin Immunol. 2003;111:S262.

24. Schwartz DA, Pardi DS, Murray JA. Use of montelukast as steroid-sparing agent for recurrent eosinophilic gastroenteritis. Dig Dis Sci. 2001;46. https://doi.org/10.1023/a:1010682310928

25. Urek MC, Kujundžić M, Banić M, Urek R, Veić TŠ, Kardum D. Leukotriene receptor antagonists as potential steroid sparing agents in a patient with serosal eosinophilic gastroenteritis. Gut. 2006:55:1363.

26. Menon J, Venkatesh V, Bhatia A, Rana SS, Lal SB. Ascites: an unusual presentation of eosinophilic gastroenteritis in a child. Trop Doct. 2020;50. https://doi.org/10.1177/0049475520911230.

27. Vithayasai N, Jennuvat S, Lertsatit A. Eosinophilic gastrointestinal disease: analysis of sixteen cases from ten years experience in Thailand. J Med Assoc Thai. 2011;94 Suppl 3. Available: https://pubmed.ncbi.nlm.nih.gov/ 22043753/.

28. Ito J, Fujiwara T, Kojima R, Nomura I. Racial differences in eosinophilic gastrointestinal disorders among Caucasian and Asian. Allergol Int. 2015;64 https://doi.org/10.1016/j.alit.2015.02.003.

\section{Publisher's Note}

Springer Nature remains neutral with regard to jurisdictional claims in published maps and institutional affiliations. 